\title{
SISU OU VESTIBULAR? \\ A POLÍTICA DE ACESSO NO CONTEXTO DE UMA UNIVERSIDADE PÚBLICA DO INTERIOR DA BAHIA
}

\author{
SISU OR ENTRANCE EXAM? \\ THE ACCESS POLICY IN THE CONTEXT OF A PUBLIC UNIVERSITY IN THE INTERIOR OF BAHIA
}

Daniel Cardoso Alves ${ }^{1}$

Submetido em: 09/10/2020

Revisões requeridas: 22/04/2021

Aprovado em: 14/09/2021

\section{RESUMO}

A ampliação da oferta de vagas nas instituições públicas de ensino superior apresenta-se como uma das vinte e uma estratégias estabelecidas no Plano Nacional de Educação para a consecução da Meta 12. Essa Meta, no bojo das suas estratégias, assume um caráter quali-quantitativo à medida que vincula a ampliação do número de matrículas à garantia social de participação proporcional nas vagas ofertadas para grupos socioeconomicamente desfavorecidos. Com o objetivo de avaliar o alcance dessa Meta, a pesquisa, que ora se apresenta, analisou, no período de 2012 a 2016, a política de acesso nos cursos de graduação da Universidade Estadual do Sudoeste da Bahia. Para isso, adotou como procedimentos a revisão bibliográfica e as pesquisas documental e de campo. Os resultados obtidos refutaram a hipótese de que a substituição do Vestibular pelo SiSU impactaria negativamente nos dados institucionais. Pelo contrário, nota-se que há similaridades de dados em ambos os processos seletivos, inclusive, com relação à origem geográfica dos discentes.

PALAVRAS-CHAVE: Plano Nacional de Educação. SiSU. Vestibular.

\section{ABSTRACT}

The expansion of the offer of vacancies in public institutions of higher education is one of the twenty-one strategies established in the National Education Plan for achieving Goal 12. This Goal, within the range of its strategies, assumes a quali-quantitative character as it links the expansion of the number of enrollments to the social guarantee of proportional participation in the vacancies offered to socioeconomically disadvantaged groups. In order to evaluate the achievement of this Goal, the research, which is now presented, analyzed, in the period from 2012 to 2016, the access policy in undergraduate courses of the State University of Southwest Bahia. For this, it adopted as procedures the bibliographic review and documentary and field research. The results obtained refuted the hypothesis that the replacement of vestibular by SiSU would negatively impact institutional data. On the contrary, it is noted that there are similarities of data in both selection processes, including the geographical origin of the students.

KEYWORDS: National Education Plan. SiSU. Entrance exam.

\footnotetext{
${ }^{1}$ Doutorando em Educação FaE/UFMG. Professor da FaE/UEMG. Mestre em Ciências Ambientais, Especialista em Análise do Espaço Geográfico, Licenciado em Geografia pela UESB/BA. E-mail: dca.uemg@gmail.com
} 


\section{INTRODUÇÃO}

Das vinte e uma estratégias estabelecidas no PNE para o alcance da meta 12 - elevação da taxa bruta de matrícula e da taxa líquida entre a população de 18 (dezoito) a 24 (vinte e quatro) anos na educação superior -, a estratégia classificada como 12.16 - "consolidar processos seletivos nacionais e regionais para acesso à educação superior como forma de superar exames vestibulares isolados" (BRASIL, 2014) -, associa-se diretamente com o objetivo desta pesquisa, que constitui-se em analisar os dados de acesso no contexto de uma instituição pública de ensino superior localizada no interior do estado da Bahia. Para tanto, compara-se, nesta pesquisa, o comportamento desses dados nos dois processos seletivos realizados em concomitância, no período de 2012 a 2016, pela instituição investigada: o Vestibular e o Sistema de Seleção Unificada (SiSU).

Diante do supracitado objetivo, a questão central da pesquisa é: Há vantagem(ns) do SiSU em relação ao Vestibular em termos de acesso aos cursos de graduação ofertados por uma instituição pública de ensino superior?

Em busca por respostas a essa questão, os dados da política de acesso dos 47 (quarenta e sete) cursos de graduação da Universidade Estadual do Sudoeste da Bahia (UESB) são o objeto deste estudo, os quais foram coletados junto à Pró-Reitoria de Graduação (PROGRAD) da referida instituição. Esses dados, ao serem complementados pela entrevista semiestruturada realizada com a respectiva pró-reitora, contribuíram significativamente para uma fidedigna sistematização e análise qualitativa dos mesmos.

Almeja-se que a metodologia, aqui apresentada, seja utilizada por outras instituições de educação superior, em diferentes modalidades e níveis de ensino, como procedimento metodológico eficaz para a avaliação dos êxitos dos seus processos seletivos, especialmente, no que concerne à implementação autônoma e consciente de políticas de acesso atentas à consecução da meta 12 estabelecida no PNE.

Este artigo estrutura-se em cinco seções, incluindo esta introdução. Na seção 1, são realizadas reflexões sobre as recentes políticas de acesso ao ensino superior num contexto censitário desigual entre sistemas de ensino. Sequencialmente, é explicitada a metodologia da pesquisa. A terceira seção destina-se à apresentação e interpretação dos resultados obtidos. E na última seção, são apresentadas as considerações finais.

\section{AS DESIGUALDADES CENSITÁRIAS ENTRE SISTEMAS DE ENSINO, AS POLÍTICAS DE ACESSO REPARA- DORAS E A QUESTÃO DO ALCANCE DA META 12 DO PNE}

De acordo com os dados do Censo da Educação Superior no Brasil (2017), o número total de ingressos na rede estadual por processos seletivos (Vestibular, Enem, Avaliação Seriada e Seleção Simplificada) foi de 181.665 (cento e oitenta e um mil, seiscentos e sessenta e cinco) mil estudantes, o que representa aproximadamente $6 \%$ (seis por cento) do número geral de ingressos registrados no Censo de $2017 \mathrm{em}$ toda a rede de ensíno superior no Brasil, totalizados em 3.226.249 (três milhões, duzentos e vinte e sei mil, duzentos e quarenta e nove) estudantes. Desse número geral, estratifica-se que $82 \%$ (oitenta e dois por cento) representam o ingresso na rede privada de ensino, ao passo que apenas $18 \%$ (dezoito por cento) equivalem ao quantitativo de ingressos na rede pública de ensino superior.

A condição atual desses dados, segundo Houri (2018), é reflexo de que

A educação superior no Brasil passou, portanto, por um processo de expansão do seu sistema com a ampliação do acesso que se expressa tanto pelo relevante aumento do número de matrículas nas duas últimas décadas - traduzindo o esforço de fazer com que passemos de um sistema de elite para um sistema de massa - quanto pela mudança de perfil dos alunos ingressantes, como podemos verificar abaixo: de pouco mais de 2,5 milhões de estudantes em 2000, passou para mais de 6.5 milhões em 2011 e ultrapassou a cifra de 8 milhões em 2015 (INEP, 2015) [...] Não se trata apenas de mudanças quantitativas. Dois efeitos importantes da expansão do ensino superior são a diversificação da população estudantil e a diferenciação interna dos sistemas nacionais. No que tange ao primeiro aspecto, os estudantes de ensino superior hoje 
constituem um conjunto muito heterogêneo em termos de idade, gênero, origem socioeconômica, cor, etnia, motivações, expectativas e projetos profissionais (p. 123-124).

A configuração de um corpo discente cada vez mais diversificado no ensino superior apresenta-se como uma das metas estabelecidas no PNE, o qual possui regime decenal e passou a vigorar no Brasil em 2014. Com a consecução desse Plano, espera-se que até o ano de 2024 as 20 (vinte) metas, no conjunto das 254 (duzentas e cinquenta e quatro) estratégias estabelecidas, resultem num salto quali-quantitativo da educação superior no país.

Todavia, preocupa o fato de que, ao se comparar os dados do Censo da Educação Superior do ano de 2017, com os registrados no Censo de 2014, quando teve início o decênio do PNE vigente, constata-se que, em três anos de vigência do referido Plano, a evolução do número total de ingressos na rede estadual ${ }^{2}$ por processos seletivos (Vestibular, Enem, Avaliação Seriada e Seleção Simplificada) foi de 22\% (vinte e dois por cento); o ingresso na rede privada, já em 2014, representava mais de $82 \%$ (oitenta e dois por cento) do número geral de ingressos no ensino superior no Brasil, superando os menos de $18 \%$ (dezoito por cento) representados pela rede pública ${ }^{3}$, situação que praticamente permaneceu estática no Censo de 2017; e o número geral de ingressos no ensino superior evoluiu em exatos 115.401 (cento e quinze mil e quatrocentos e um) estudantes, o que representa uma lenta evolução de aproximados $4 \%$ (quatro por cento) num período de três anos. Ao mesmo tempo,

No Brasil, a proporção de concluintes em relação aos ingressantes é baixíssima. Por que que são tão poucos? [...]. Por que são tão poucos que conseguem completar o ensino superior? Mesmo tendo mais vagas, mesmo incluindo pessoas que são as primeiras de suas famílias a entrarem no ensino superior, ainda temos dificuldade para dizer que esse nível se democratizou efetivamente, porque pouca gente consegue chegar até o fim (BARBOSA, 2018, p. 24).

Ao analisarmos a situação censitária da educação superior no Brasil, à primeira vista, constatamos que, com relação à rede privada, ela, de fato, abarca os maiores números de ingressos no ensino superior, ao passo que a rede pública, com base no detalhamento dos dados por unidades da federação (municipal, estadual e federal), teve tímidos aumentos nos números de ingressos no período de 2014 a 2017 nas redes estadual e federal de ensino superior no Brasil, sendo que na rede estadual essa evolução foi maior do que na rede federal, entretanto, as instituições federais, isoladamente, continuam a representar quase $50 \%$ (cinquenta por cento) do número de ingressos no ensino público superior. A única exceção, apreendida da análise comparativa entre os Censos da Educação Superior 2014 e 2017, consiste na queda de $51 \%$ (cinquenta e um por cento) do número de ingressantes na rede municipal ${ }^{4}$.

Contudo, é por demais ilusório restringir a análise desses dados baseando-se na oposição público e privado, visto que a oferta expressiva de vagas na rede privada não é fator que determina a inibição do aumento do número de vagas na rede pública. Pelo contrário, o que se observa é uma estabilização dessa oferta em função do pouco investimento na ampliação das redes estadual e federal de ensino, sobretudo nos últimos anos. A esse respeito, Barbosa (2018) ao discorrer sobre a massificação e democratização no ensino superior, nos provoca a aprofundar a reflexão sobre o debate entre público e privado, considerando que:

A literatura tem indicado que a segmentação do sistema entre público e privado permite um tipo de expansão que pode "divergir" os alunos dos grupos sociais não-elite - os pobres, pretos, e mulheres - para os segmentos menos privilegiados do sistema. O sistema se abre, mas dirige os alunos menos poderosos socialmente para os cursos menos prestigiados. De alguma forma, me parece que o viés acadêmico do desenho institucional da universidade brasileira favorece esse fenômeno. O modelo único vigente, de ins-

\footnotetext{
${ }^{1}$ Doutorando em Educação FaE/UFMG. Professor da FaE/UEMG. Mestre em Ciências Ambientais, Especialista em Análise do Espaço Geográfico, Licenciado em Geografia pela UESB/BA. E-mail: dca.uemg@gmail.com
} 
piração humboldtiana, que implica que toda instituição "tem que ser 'USP'”, e que mesmo instituições que oferecem cursos tecnológicos ou de licenciatura precisam seguir o padrão de "universidade de pesquisa", acaba por sobrevalorizar o bacharelado em detrimento dos demais graus acadêmicos. Por último, dois fatores institucionais estão associados à segregação dentro do ensino superior: seletividade e turno dos cursos - que precisa ser melhor estudado (BARBOSA, 2018, p. 26-27).

Esse comportamento estatístico entre os entes da federação e as diferenças entre o ensino público e privado pode encontrar fundamento nas disposições constitucionais sobre as competências da União, dos Estados e dos Municípios. Conforme dispõe a Constituição Federal de 1988, à União compete, prioritariamente, o ensino superior e a educação profissional; aos Estados e Distrito Federal, a prioridade deve ser o ensino fundamental e médio; e aos Municípios, a responsabilidade principal é o ensino fundamental e a educação infantil. Ainda, o texto constitucional evidencia que a educação, enquanto direito social gratuito, é garantida somente até os anos elementares e fundamentais de ensino.

Também infere-se da análise comparativa dos dados censitários 2014 e 2017, sem desconsiderar a influência do curto intervalo de tempo evolutivo, que provavelmente o lento crescimento do número geral de ingressos no ensino superior ao longo dos três anos de execução do PNE pode estar associado à mitigada ampliação na oferta do número de novas vagas destinadas ao ensino superior, uma vez que, de acordo com o Censo da Educação Superior de 2017, além de não ter havido decréscimo nos números de ingressos, de uma forma geral, tanto na rede pública quanto na rede privada, a oferta de novas vagas verificada no Censo da Educação Superior do ano de 2014 ficou em torno dos $22 \%$ (vinte e dois por cento).

Com relação à oferta de novas vagas nas redes privada e pública, segundo os Censos dos anos de 2014 e 2017, a primeira representa aproximadamente 91\% (noventa e um por cento) das vagas existentes no ensino superior, restando apenas $9 \%$ (nove por cento) para a rede pública, sendo que continua crescente a criação de novas vagas na rede privada, na qual, de 2014 a 2017, houve um crescimento duas vezes maior (dezenove por cento) na oferta de novas vagas em comparação à rede pública, que aumentou a sua oferta em menos de $10 \%$ (dez por cento).

Ao vincular a análise desses dados censitários com a meta 12 do PNE, que é elevar, na educação superior, em $50 \%$ (cinquenta por cento) a taxa bruta de matrícula e, em $33 \%$ (trinta e três por cento), a taxa líquida para da população de 18 (dezoito) a 24 (vinte e quatro) anos para 50\% (cinquenta por cento), ampliando, ainda, em pelo menos, $40 \%$ (quarenta por cento) as novas matrículas no segmento público, preocupa a inexpressividade da evolução do número geral de ingressos no ensino superior (quatro por cento), após três anos de execução do Plano, que é intensificada pela manutenção de uma discrepância gigantesca entre as ofertas de novas vagas (noventa e um por cento) e o número de ingressos (oitenta e dois por cento) registrados na rede privada em relação aos constatados na rede pública. Se esse ritmo for mantido, estatisticamente a citada meta dificilmente será cumprida dentro do prazo que ainda resta para se atingir o decênio estabelecido para a vigência do PNE.

Esses dados são reflexos das diversas políticas públicas voltadas para a expansão da graduação no Brasil nas redes pública e privada, sendo notória, ainda que também mitigada em termos gerais e de demanda social, a intensificação de ações públicas direcionadas para a rede privada. Num curto recorte temporal das últimas duas décadas, verifica-se a implementação de duas políticas de ampliação dos ingressos na rede privada de ensino superior, as quais estão expressamente vinculadas com as estratégias 12.5, 12.6 e 12.20 fixadas para a meta 12 do PNE, e vêm contribuindo demasiadamente para a evolução dos ingressos nas instituições privadas, são elas: Fundo de Financiamento Estudantil (Fies) e Programa Universidade para Todos (Prouni).

O objetivo do Fies é financiar, com recursos públicos, a inserção de estudantes com renda familiar per capta não superior a dois salários mínimos em Instituições de Ensino Superior (IES) privadas, teto este estabelecido no Decreto $n^{\circ} 8.498$, de 10 de agosto de 2015. Esse financiamento público, com base nos critérios estabelecidos pelo Ministério da Educação (MEC), pode ocorrer em regime parcial ou total. De acordo com os dados dos relatórios de gestão do Fies, disponíveis no portal eletrônico do MEC, em quinze anos de vigência do Fundo, o número de 
estudantes contemplados sextuplicou e os recursos públicos destinados ultrapassaram a casa dos milhões, ou seja, saltou de 629 (seiscentos e vinte e nove) milhões para mais de 12 (doze) bilhões de reais. No entanto, esses números ainda não respondem à demanda em sua totalidade, o que ensejou, a partir do ano de 2009, a adoção de algumas medidas beneficiadoras voltadas para aqueles estudantes mais desfavorecidos socioeconomicamente, tais como: a prioridade na adesão ao Fies a estudantes com menor renda familiar, negros, indígenas, egressos de escolas públicas e que não são portadores de diploma de curso superior anterior.

Em atuação paralela ao Fies, foi implementado no ano de 2005 o Prouni com o objetivo de oferecer bolsas integrais para estudantes com renda familiar per capta de até um salário mínimo e meio e bolsas parciais para aqueles com renda familiar per capta não superior a três salários mínimos. Essas bolsas destinam-se ao custeio das mensalidades de matrícula desses estudantes em cursos de graduação das IES da rede privada, buscando, ao mesmo tempo, mitigar as desigualdades sociais por meio da inserção de cotas aos candidatos autodeclarados como pretos e pardos, indígenas, estudantes oriundos de escolas públicas ou com bolsa integral, pessoas com deficiência e professores da rede pública não portadores de diploma de curso superior.

De acordo com os dados divulgados pelo Prouni no ano de 2015, em dez anos de vigência, o Programa conseguiu contemplar mais da metade (cinquenta e dois por cento) da população negra nele inscrita. Entretanto, questionamentos fundamentais ainda se fazem necessários, tendo em vista que o processo avaliativo desses programas, segundo especialistas, se apresenta muito falho:

Qual o impacto de cada um desses programas? Em meio ao avanço dos processos de privatização e de mercantilização do ensino superior, o financiamento público estudantil, por meio do crédito educativo, o Fies, e a isenção de impostos das instituições privadas, por meio da adesão ao Prouni, o programa de bolsas, contribuiu para 242 a consolidação de grandes grupos educacionais que hoje atuam no país. Além de terem obtido isenção fiscal, as instituições privadas com fins lucrativos passaram contar com recursos do Estado para financiaras mensalidades de seus estudantes. Operando com capital aberto em bolsas de valores e atraindo investidores internacionais, esses grupos empresariais concentram hoje cerca de um quarto do total de matrículas do setor privado. Nesse sentido, as políticas de ampliação do acesso ao ensino superior, o aumento do número de matrículas e a consolidação de um grande mercado educacional no país são fenômenos associados nas últimas décadas (SAMPAIO, 2018, p. 241-242).

Nesse sentido, Fies e Prouni configuram-se como estratégias específicas do PNE para a elevação das taxas bruta e líquida das matrículas no ensino público superior (meta 12), priorizando aqueles sujeitos sócio, econômico e culturalmente marginalizados da educação formal. Essas dimensões de caráter socioeconômico e cultural, conforme Barros et al. (2001) e Soares e Collares (2006), incluindo questões estruturais de famílias monoparentais lideradas por mulheres, segundo Hasenbalg (2002) e Mont'Alvão (2011), interferem determinantemente na trajetória escolar desses sujeitos. Essas interferências precisam ser consideradas em qualquer política educacional empenhada na mudança dos paradigmas historicamente instalados. A despeito da importância social desses programas educacionais, ainda que sejam meramente paliativos,

[...] A grave crise econômica, hoje está ameaçando seriamente o financiamento público de estudantes matriculados nas instituições privadas. Desde o final de 2014 estamos assistindo um refreamento crescente nos gastos governamentais com os programas Fies e Prouni. E isso tem sido feito por meio da adoção de várias mudanças no modo de funcionamento dos programas com um objetivo bastante claro: torná-los cada vez mais restritivos com vistas a diminuir o financiamento público. Certamente, essas medidas enfrentam a forte pressão do lobby do setor privado para aumentar o financiamento público dos estudantes por meio do Fies e para manter a isenção fiscal das instituições que aderem ao Prouni [...] (SAMPAIO, 2018, p. 244-245). 
Apesar dos êxitos inerentes a essas estratégias (Fies e Prouni), que se consolidam em políticas educacionais, não se pode negligenciar o ensino público, uma vez que, o estímulo demasiado ao ingresso de estudantes na rede privada de ensino superior, valendo-se, para tanto, de recursos públicos, retira, indiretamente, a possibilidade de maiores investimentos na rede pública, camuflando a realidade e apontando, inclusive, para a construção de um imaginário social determinista em que, conforme Bourdieu (2004),

[...] Quem quiser ganhar nesse jogo, apropriar-se do que está em jogo, apanhar a bola, ou seja, por exemplo, um bom partido e as vantagens a ele associadas, deve ter o sentido do jogo. É preciso falar de regras? Sim e não. Pode-se fazê-lo desde que se distinga claramente regra de regularidade. O jogo social é regrado, ele é lugar de regularidade. Nele as coisas se passam de modo regular[...] (p. 82 e 83).

Esse cursus tem origem nos anos iniciais da formação, contribuindo, desde a sua origem, para o insucesso escolar de uma parcela da população constituída historicamente, conforme Coleman et al. (1966) em referência ao contexto norte-americano de 1960, por famílias negras desestruturadas socioeconomicamente, Ihes restando, tão somente, aspirar por financiamentos públicos em IES privadas.

Todavia, a lógica deveria ser a de possibilitar, cada vez mais, que aquele sujeito com formação básica deficitária e marginalizado sócio, econômico e culturalmente tivesse as condições para ele próprio, escolher a rede de ensino, fosse ela privada ou pública, e o curso de graduação de sua opção, o que significaria uma trajetória não previamente determinada por outrem.

Quanto às políticas voltadas para a ampliação da graduação na rede pública de ensino, três merecem destaques por terem impactado IES federais e estaduais: a Universidade Aberta do Brasil (UAB) em 2006, instituída por força do Decreto Federal $n^{\circ} 5.800$, de 08 de junho de 2006; o SiSU, criado em 2010 pela Portaria Normativa MEC $n^{\circ}$ 2, de 26 de janeiro de 2010, alterada pela Portaria Normativa MEC $n^{\circ}$ 21, de 05 de novembro de 2012; e as Ações Afirmativas instituídas em 2012 por meio da Lei Federal n 12.711, de 29 de agosto de 2012, e regulamentada pelo Decreto Federal $n^{\circ} 7.824$, de 11 de outubro de 2012.

No que concerne ao SiSU, foco deste estudo, a sua implementação esteve associada, segundo os discursos oficiais, à possibilidade de tornar o acesso mais democrático ao ensino superior na rede pública, constituindo-se em um sistema informatizado que, gerenciado pela Secretaria Superior de Educação do MEC, teria como objetivo selecionar estudantes para o preenchimento de vagas em cursos de graduação, as quais são disponibilizadas pelas IES que dele participam. O processo de seleção se dá exclusivamente com base nos resultados obtidos pelos estudantes no Exame Nacional do Ensino Médio (Enem).

Esse Exame foi criado pela Portaria do MEC n 438, de 28 de maio de 1998, alterada pela Portaria do MEC $n^{\circ}$ 807, de junho de 2010, para compor o papel do "Estado-avaliador"5, predominante naquele contexto, e se constituiu como uma das primeiras políticas em educação com o objetivo de mensurar os resultados do rendimento escolar dos alunos ao fim da escolaridade básica, por meio da aplicação de testes em larga escala, com ênfase na eficiência e eficácia das escolas.

A criação do ENEM veio a calhar com a LDBEN de 1996, a qual estabeleceu a flexibilização nas formas de acesso ao ensino superior, pois, até então, a lei que estava em vigor exigia somente o vestibular para ingressar nesse nível de ensino. Em 2009, o Ministério da Educação (MEC) propôs às IFES, por meio do documento Proposta à Associação Nacional dos Dirigentes das Instituições Federais de Ensino Superior, que utilizassem o ENEM como prova para seleção dos candidatos em vez dos vestibulares próprios. Para isso, o MEC/ INEP realizou uma reestruturação metodológica do exame (KLITZKE, 2018, p. 155-156).

\footnotetext{
${ }^{5}$ Nas palavras de Afonso (2009, p. 46) essa expressão remete à ideia da "lógica do mercado, através da importação para o domínio público de modelos de gestão privada, com ênfase no resultado e nos produtos dos sistemas educativos." Para o autor, trata-se de um novo darwinismo social, em que a avaliação assume um papel central nas recentes reformas na administração pública.
} 
No que diz respeito ao estabelecimento do SiSU como processo seletivo para os cursos de graduação, a portaria que estabelece as principais mudanças no Enem em relação ao modelo anterior é a de número 109 de 27 de maio de 2009. Com a vigência dessa portaria, a principal alteração que se deu foi no formato da prova, cuja intenção era adequá-lo para a utilização enquanto instrumento de diversas políticas públicas de acesso ao ensino superior (Fies, Prouni e o próprio SiSU), ultrapassando, dessa forma, o caráter inicial de um exame com fim unicamente avaliativo para um instrumento de alcance da estratégia 12.16 do $\mathrm{PNE}$, como possibilidade de processo seletivo único para ingresso no ensino superior, o que, na perspectiva de "Estado-avaliador" formulada por Afonso (2013), tem como finalidade última cumprir a estratégia do que está em curso, ou seja, cumprir a "estratégia de exacerbação e diversificação de lógicas neoliberais de transnacionalização da educação, com ênfase na privatização, mercadorização e mercantilização" (Afonso, 2013, p. 276).

O SiSU, assim, apresentou-se como uma importante estratégia da política educacional de expansão do acesso ao ensino superior. Acesso que, parafraseando Blau \& Duncan (1967), continua sendo a via mais importante para a mobilidade social, sobretudo, de grupos historicamente marginalizados por questões socioeconômicas e raciais. Ao valer-se de um exame unificado, o SiSU permite a participação dos candidatos nas próprias cidades onde moram, sendo gratuito para mais de $70 \%$ (setenta por cento) dos inscritos e ancora-se, sobretudo, na justificativa de tornar o acesso mais democrático ao ensino superior, uma vez que, o resultado de um mesmo exame passou a ser utilizado por diversas IES e para diferentes políticas educacionais, inclusive aquelas relacionadas à permanência estudantil. Essa nova forma de acesso ao ensino superior, por todos esses atrativos, além da contrapartida financeira às IES que a ela aderem, representou não só a aspiração pelo aumento dos números de ingressos em cursos superiores da rede pública, como a maximização das ações voltadas à assistência estudantil, diante dos recursos financeiros repassados pelo governo federal por meio do Programa Nacional de Assistência Estudantil (PNAES) para as Instituições de Educação Superior Públicas Estaduais (PNAEST), instituído pelo Decreto Federal $n^{\circ} 7.234$, de 19 de julho de 2010. Esse Sistema constitui-se de etapas sucessivas, as quais são assim definidas:

I- Oferta de vagas no SISU pelas instituições participantes, disponibilizadas para inscrição dos candidatos; II- inscrição no SISU dos candidatos que tenham participado do ENEM a partir da edição referente ao ano anterior; III- seleção e classificação dos candidatos com base no desempenho no ENEM, observados os pesos e as notas mínimas eventualmente estabelecidos pela instituição; IV- lançamento das vagas ocupadas no SISU (BRASIL, 2010).

Pelo exposto, o SiSU como nova política unificada de acesso ao ensino superior público pela maioria das IES brasileiras constitui-se como uma dentre as muitas estratégias supostamente empenhadas na ampliação das ofertas de vagas nas universidades, com vistas a aumentar o número de ingressantes em taxas bruta e líquida, de forma proporcional e mais justa, garantindo o acesso de grupos sociais diversos ao ensino superior no Brasil, o qual, de acordo com Brito (2014), independente de qual seja a classe socioeconômica, está distante de atingir a sua saturação, visto que, ao mesmo tempo em que se verifica avanços na adoção de formas híbridas de acesso ao ensino superior,

[...] O SISU se aproxima dos vestibulares tradicionais que recrutam alunos para ingressar nas (IES), mas também deles se distancia ao centralizar em um único exame e sistema de seleção a oportunidade de ingressar em uma universidade pública de qualquer estado da federação (KLITZKE; SANTOS; VALLE, 2013 apud KLITZKE, 2018).

Com raízes fincadas num processo tradicionalista de seleção de estudantes (o vestibular), o SiSU carrega consigo características da centralização, da exclusão e da segmentação social. Nesse sentido, essa política educacional não se restringe a um fim em si mesma, ou seja, ao acesso, já que, ao constituir-se como um instrumento inicial, a ideia de continuidade the é inerente, o que significa dizer que o seu êxito não é isolado, perpassa pela garantia 
das condições para aquele que, através dela teve acesso à universidade, tenha, efetivamente, a possibilidade de permanecer na universidade até a obtenção do seu tão almejado diploma de nível superior.

Por fim, é preciso esclarecer que quase a totalidade das IES, até o momento, aderiram ao SiSU como forma exclusiva de acesso aos cursos de graduação por elas ofertados, sendo raras exceções aquelas que ainda preenchem parte das vagas por meio do SiSU e outra parte por meio do vestibular próprio, como é o caso da UESB, lócus deste estudo.

\section{PROCEDIMENTOS METODOLÓGICOS}

A pesquisa realiza-se na UESB, uma entidade autárquica, dotada de personalidade jurídica de direito público interno e regime especial de ensino, pesquisa e extensão, de caráter multicampi, com sede e foro no município de Vitória da Conquista, estado da Bahia.

A UESB oferta, segundo o seu Plano de Desenvolvimento Institucional 2013-2017 (PDI), 47 (quarenta e sete) cursos de graduação, abrangendo 07 (sete) áreas de conhecimento (Ciências Exatas e da Terra, Engenharias, Saúde, Ciências Agrárias, Ciências Sociais Aplicadas, Ciências Humanas e Artes), ofertados nos 03 (três) turnos contemplados (matutino, vespertino e noturno) e divididos em dois níveis (vinte e cinco bacharelados e vinte e duas licenciaturas). Esses níveis estão distribuídos nos campi da instituição da seguinte forma: vinte e dois (doze bacharelados e dez licenciaturas) existentes no Campus de Vitória da Conquista, dezesseis (oito bacharelados e oito licenciaturas) alocados no Campus de Jequié, e nove (cinco bacharelados e quatro licenciaturas) pertencentes ao Campus de Itapetinga.

É uma instituição que tem como missão formar profissionais-cidadãos, visando à promoção do desenvolvimento humano, bem como se constituir como referência em educação e transformação social, sobretudo, nos territórios de identidade de Vitória da Conquista, Médio Rio de Contas (Jequié) e Médio Sudoeste da Bahia (Itapetinga), além do norte de Minas Gerais, nos quais impacta diretamente no desenvolvimento socioeconômico, ambiental, tecnológico e na oferta dos serviços de saúde e educação dos municípios que integram esses territórios.

A escolha da UESB como lócus do estudo deve-se ao fato de que essa IES foi uma das pioneiras, a nível estadual, a adotar o SiSU como política de acesso aos cursos de graduação no Brasil (ano de 2012, ou seja, apenas dois anos após a sua regulamentação pela Portaria Normativa n. ${ }^{\circ} 2$, de 26 de janeiro de 2010) e, ao mesmo tempo, apresenta-se na atualidade como uma das poucas universidades públicas que permanecesse com a manutenção de uma política híbrida de acesso (SiSU e Vestibular), tendo em vista a não definição pelo Conselho Universitário Superior da instituição (CONSU), até o momento, acerca da melhor forma de acesso no que garantiria êxitos não só de acesso como também de permanência e integralização curricular.

Com o objetivo de analisar os dados sobre o acesso estudantil aos cursos de graduação da referida Universidade, comparando, para tanto, o comportamento desses dados, no período de 2012 a 2016, por meio de dois processos seletivos por ela adotados, o Vestibular e o Sistema de Seleção Unificada (SiSU), a pesquisa se estrutura em quatro etapas: revisão bibliográfica, pesquisa de campo, pesquisa documental e sistematização e análise dos resultados, os quais foram interpretados por meio da técnica análise de conteúdo.

O recorte temporal adotado justifica-se no ano em que o SiSU foi instituído na UESB, 2012, e no último Censo da Educação Superior divulgado, que apresenta os dados referentes ao ano civil de 2017, que corresponde, na UESB, devido a interrupções de semestres, ao ano letivo de 2016.

Como percurso metodológico, após densa revisão bibliográfica acerca do recente quadro das políticas educacionais de acesso presentes no cenário universitário e, com base nas recomendações necessárias para estudos de casos (Gil, 2008), adotou-se diferentes fontes e diversificados procedimentos, nesta ordem:

- Pesquisa documental no âmbito das instâncias administrativas da UESB, por meio de levantamentos, consultas e leituras dos documentos institucionais oficiais, dentre eles, o PDI 2013-2017 e as Resoluções que abordam sobre as políticas educacionais internas, bem como, por meio de consultas sistemáticas ao site da instituição à procura de dados sobre os cursos de graduação ofertados, buscando-se observar, no período de 2012 a 2016, do ponto 
de vista discursivo, a situação e o direcionamento das políticas educacionais adotadas e concernentes ao acesso aos cursos de graduação da UESB.

- Pesquisa de campo (coleta de dados e informações), cujo sujeito protagonista da pesquisa foi a Pró-Reitora de Graduação da UESB. Para tanto, utilizou-se o seguinte instrumento: entrevista semiestruturada com o apoio de roteiro, de caráter aprofundado, abordando as apreensões da Pró-Reitora, do ponto de vista da gestão, sobre a adoção do SiSU como política de acesso.

A quarta etapa da pesquisa teve como finalidade a sistematização e análise qualitativas da multiplicidade dos significados impressos na entrevista realizada, em que os conteúdos resultantes da entrevista, ao complementarem as fontes documentais e os dados levantados, preencheram lacunas importantes para a maior compreensão da temática em estudo.

\section{A POLÍTICA HÍBRIDA DE ACESSO AOS CURSOS DE GRADUAÇÃO DA UESB}

As formas, as modalidades e as condições para o ingresso nos cursos de graduação da UESB são definidas no capítulo VIII do seu Regimento Geral, dentre as quais, o SiSU não se configura, tendo em vista que essa política somente foi aderida por essa universidade no ano de 2012, ou seja, após o início da vigência desse documento institucional. Todavia, o SiSU aparece de forma genérica na resolução que dispõe sobre a matrícula na UESB, aprovada em 2009, intitulada Resolução CONSEPE/UESB $n^{\circ}$ 60/2009, como abaixo se transcreve, sendo que a sua normatização específica é dirimida por meio de editais e termos de adesão anualmente publicados.

$\S 1^{\circ}$ - São condições de ingresso nos Cursos de graduação desta UESB, com direito à matrícula: I. aprovação e classificação em processo seletivo, promovido por esta Instituição ou por órgão externo ao qual seja delegada a devida competência; II. aprovação em processo de transferência de outra instituição de ensino superior (IES), nacional ou estrangeira, segundo os procedimentos normais, ou ex-officio; III. aprovação em processo de matrícula de Portador de Diploma de Curso de Graduação; IV. aprovação em processo de reingresso de aluno anteriormente desligado desta Universidade (UESB, 2009).

A inexistência explícita da configuração do SiSU nos principais documentos que tratam do acesso estudantil à UESB é consequência de que se trata de uma política de acesso que não foi formulada pela própria UESB. A esse respeito, a pró-reitora de graduação, protagonista desta pesquisa, esclarece, em síntese, que a adesão às políticas ditas "democratizantes" de acesso ao ensino superior, a exemplo do SiSU, nasceu com a LBD (Lei de Diretrizes e Bases da Educação, 9.394/96), com os Planos Nacionais de Educação e se materializou, mais concretamente, na primeira década do ano 2000 , em que se verificou uma ascensão de classes sociais economicamente menos favorecidas ao ensino superior público e, naturalmente, um redimensionamento político de redistribuição das vagas entre as classes sociais existentes no país.

Desde então, ainda segundo a pró-reitora de graduação da UESB, o governo federal iniciou uma política de "compras" de vagas, tanto pelo seguimento privado quanto pelo público, implementando sistemas de financiamentos (Fies, Prouni, dentre outros) e, no caso das instituições públicas, o Sistema Unificado de acesso ao ensino superior, o SiSU, que vem se constituindo em um combo, que tem como via de acesso o escore de um único processo seletivo, o Enem, sob duas perspectivas: uma para a legitimação da avaliação nacional desse exame; e outra para possibilitar acontecimentos a posteriori do exame, que é o caso do acesso ao ensino superior público no Brasil.

A UESB faz a primeira adesão em 2012 num momento muito frutífero em que o Brasil discutia esse movimento, e discutia o processo de democratização do uso das vagas, que é um assunto extremamente importante, é uma linguagem de democratização que gerou muita polêmica, e traz à tona a discussão de que as vagas nas universidades públicas deveriam ser democratizadas, se não simplesmente pelo mérito, então a classe média brigou muito por conta do Sistema Unificado, por que restringiu o número de vagas para a am- 
pla concorrência no vestibular, fazendo também com que a população modificasse com o tempo, em todas as instituições de ensino superior, inclusive aqui na UESB (PRÓ-REITORA DE GRADUAÇÃO, 29/11/2017).

Para aquelas instituições que aderem ao SiSU, de acordo com o documento denominado termo de adesão que é assinado pelas IES participantes, a contrapartida diz respeito ao recebimento de um recurso financeiro que deve servir para a manutenção dos estudantes contemplados por essa forma de acesso, os quais são supostamente oriundos de escolas públicas, de baixa renda, e sem possibilidades econômicas de permanecerem fora das suas cidades. O recurso apresenta-se, assim, para as instituições, como a possibilidade de consolidarem uma política institucional de acesso e, ao mesmo tempo, a garantia da permanência estudantil.

Sobre essa contrapartida, a pró-reitora de graduação da UESB entende que o Sistema Unificado e a adesão das instituições públicas ocorreram sempre no sentido de uma "jogada de mestre", em que a universidade ao fazer a adesão é recompensada financeiramente, porém, essa recompensa é tardia e ineficaz, dada a gama de complicadores relacionados, a exemplo do descompasso entre o tempo em que o recurso chega à universidade e os trâmites da gestão necessários para a consolidação dos mecanismos de permanência, o que impede o seu eficaz aproveitamento para a promoção de ações como bolsas, auxílios alimentação, material de consumo, material permanente, entre outros, destinados aos estudantes contemplados com o SiSU.

Ainda que não tenha sido uma política de acesso elaborada pela própria UESB, o SiSU foi adaptado à realidade institucional, sendo vinculado às outras políticas internas, dentre as quais, ao Programa de Ações Afirmativas, em que por meio da Resolução CONSEPE/UESB n $37 / 2008$ é estabelecida a reserva de $50 \%$ (cinquenta por cento) do número de vagas destinadas para candidatos étnico-raciais autodeclarados ${ }^{6}$ e oriundos de escolas públicas, cuja perspectiva é de não somente garantir o acesso, mas, contemplar, de forma proporcional, aqueles que, historicamente, por condições socioeconômicas e culturais, não vislumbravam sequer a possibilidade do acesso ao ensino superior.

Essas políticas podem ser vistas como medidas para criar igualdade de oportunidades para grupos e populações socialmente excluídos, uma vez que predizem um tratamento diferenciado em sua execução, com o objetivo de ampliar a inserção desses grupos ou populações na educação, no mercado de trabalho, na saúde, entre outros. Dessa forma, é possível pensar as políticas de ação afirmativa como um nivelamento de campo para tornar a igualdade de oportunidades uma realidade (HERINGER, 1999). No entanto, essa discussão é, de certa forma, nova no Brasil, ganhando mais visibilidade com a III Conferência Mundial de Combate ao Racismo, Discriminação Racial, Xenofobia e Intolerâncias Correlatas, que ocorreu em 2001, na cidade de Durban, na África do Sul. Segundo alguns estudiosos, nesse evento, o Brasil se posicionou a favor de políticas que favoreçam grupos historicamente discriminados, comprometendo-se, pela primeira vez, com a implantação de políticas de ações afirmativas nas instituições de ensino superior (OLIVEN, 2009; HERINGER, 2013 apud KLITZKE, 2018, p. 158).

Assim, a partir da adoção de um critério híbrido de seleção, mesclando-se vagas entre o tradicional vestibular e o SiSU, iniciado no primeiro período letivo de 2012, e vinculado a uma política de ação afirmativa já em execução desde o ano letivo de 2009 , temos o seguinte quadro de ocupação das vagas nos cursos de graduação da UESB:

\footnotetext{
${ }^{6}$ Conforme dispõe a Resolução que dirime a política de cotas na UESB, o enquadramento como pertencente à população negra (preto e par-
}

do) dar-se-á pelo preenchimento pelos candidatos de um termo padrão de autodeclaração de sua identidade étnico-racial fornecido pela UESB. 


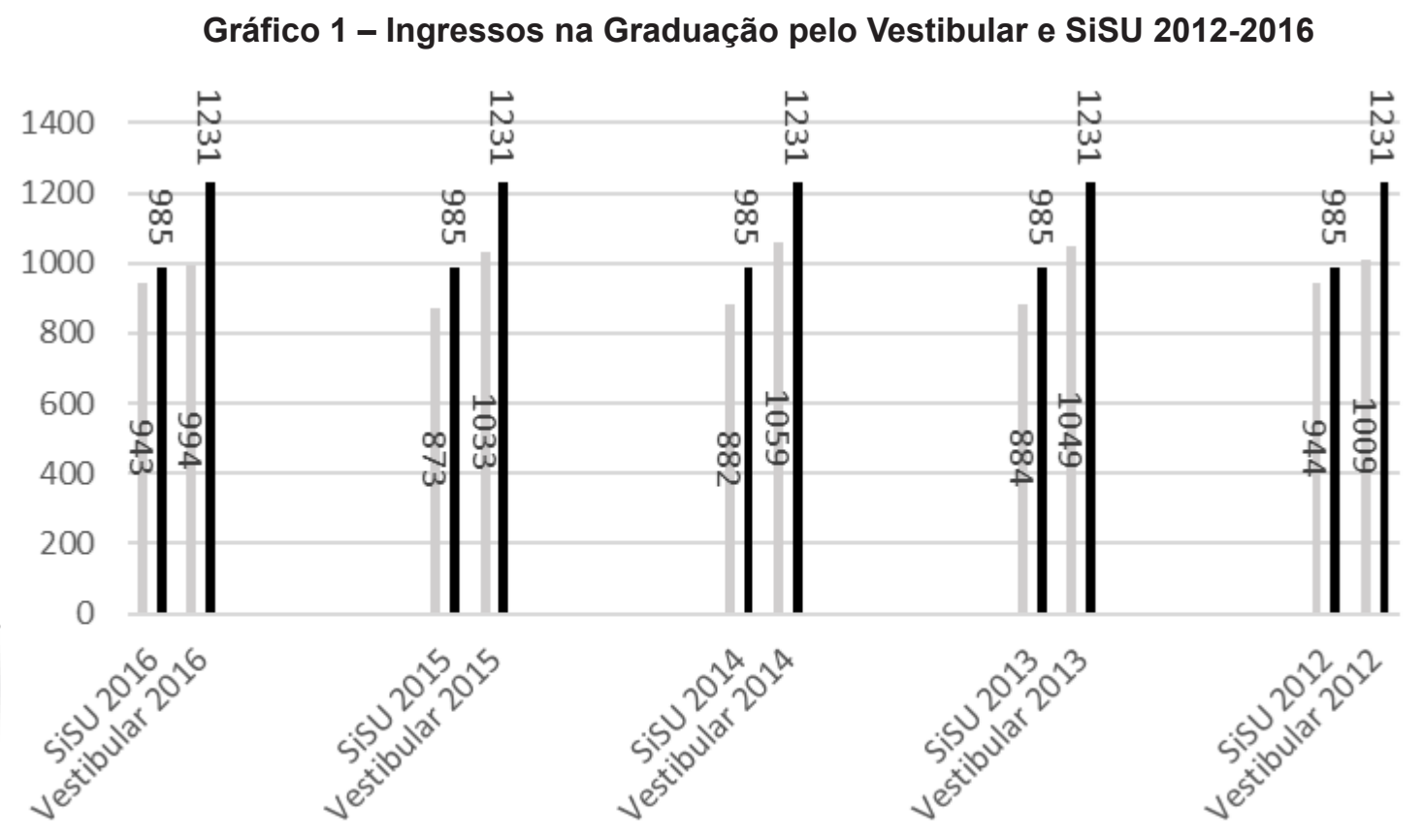

Ingressos $\mathbf{\square}$ Oferta de vagas

Fonte: Dados da pesquisa.

Constata-se que, em ambas as formas (Vestibular e SiSU), há um percentual de preenchimento próximo dos $90 \%$ (noventa por cento) das vagas ofertadas, as quais calculam-se, anualmente, em 1.231 (um mil, duzentos e trinta e uma) e 985 (novecentos e oitenta e cinco) destinadas ao Vestibular e ao SiSU7 ${ }^{7}$, respectivamente.

Quando se compara a evolução de matrícula nos processos de seleção adotados pela UESB, percebemos que o número de estudantes que ingressam através do SiSU é quase proporcional ao que ingressa pelo Vestibular, e o percentual de ocupação das vagas pelo SiSU tem se mantido, o que também é percebido no Vestibular, porém, devido ao fenômeno do baixo aproveitamento das vagas destinadas às cotas adicionais, que desde o ano letivo de 2013 passaram a ser ofertadas exclusivamente por meio do Vestibular, verifica-se um menor percentual de preenchimento das vagas anualmente ofertadas por esse processo seletivo, considerando os totais anuais descritos no parágrafo anterior, o que totaliza 2.216 (duas mil, duzentos e dezesseis) vagas anuais ofertadas pela UESB, conforme se observa no gráfico 2 :

\footnotetext{
${ }^{7} \mathrm{Na}$ UESB, a partir do ano letivo de 2013 as cotas adicionais tornaram-se exclusivas do Vestibular. Visando a redução da ociosidade das vagas destinadas ao SiSU, as convocações passaram a ser realizadas em duas edições anuais e houve a restrição das opções de escolhas pelos candidatos a apenas duas IES.
} 


\title{
Gráfico 2 - Evolução de matrículas na graduação Vestibular/SiSU 2012-2016
}

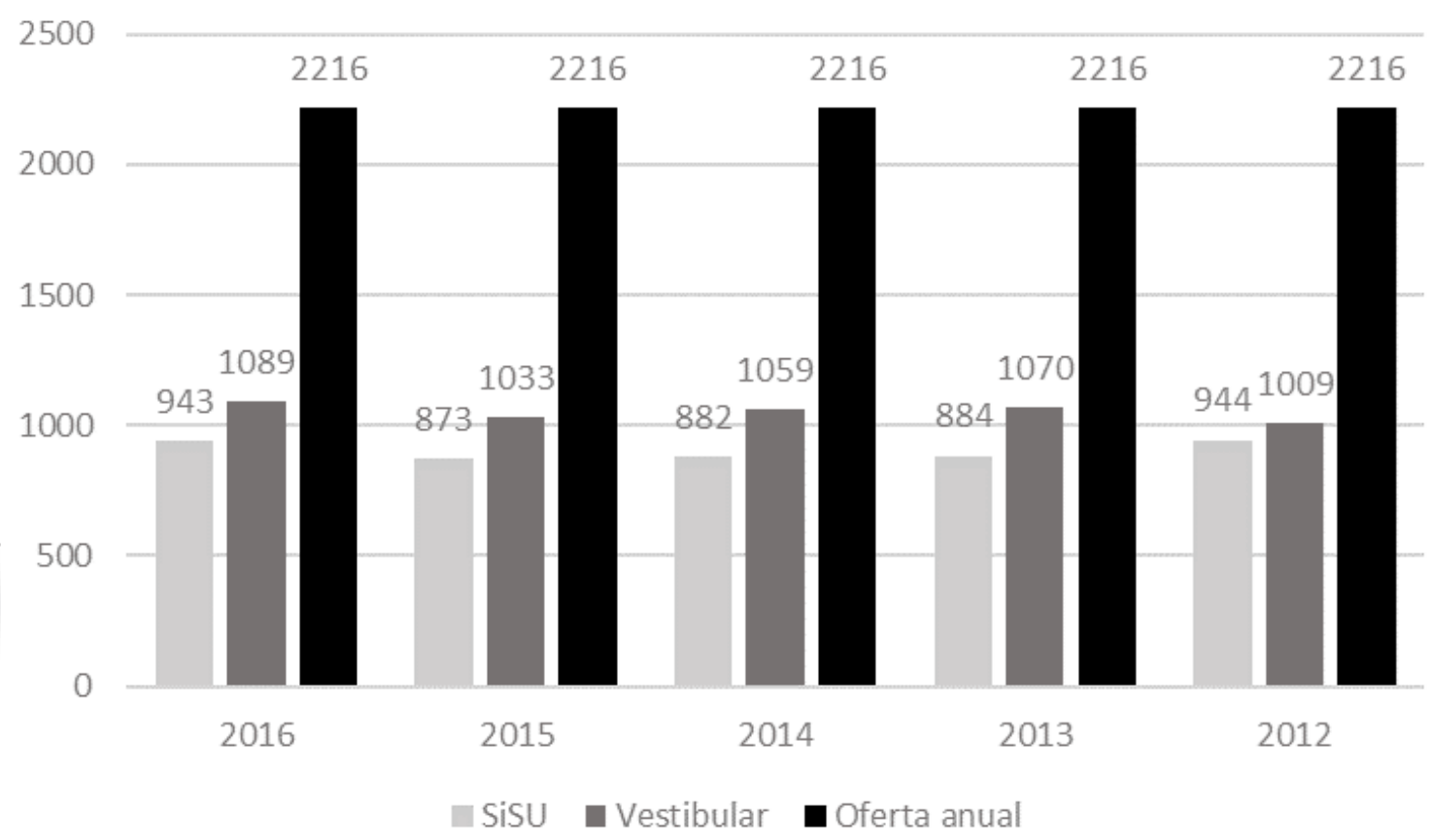

Fonte: Fonte: Dados da pesquisa.

Da análise do gráfico 2, apreende-se que há na UESB um percentual de $86 \%$ (oitenta e seis por cento) de aproveitamento das vagas ofertadas/ano, cujo número absoluto de matrículas ${ }^{8}$, pelo Vestibular, mantém-se estabilizado em um pouco mais de um mil estudantes em relação a uma oferta anual de 1.048 vagas (um mil e quarenta e oito, sem cotas adicionais) e 1.231 vagas (um mil, duzentos e trinta e uma, com cotas adicionais) e, pelo SiSU, observa-se um total aproximado de 900 (novecentas) matrículas/ano, cuja oferta anual de vagas é 985 (novecentos e oitenta e cinco).

Esse comportamento de ocupação de vagas muito semelhante em ambos os processos seletivos, aqui em análise, reforça a ideia de que o recrutamento mitigado de estudantes, conforme advertem Klitzke, Santos e Valle (2013), é a regra que une SiSU e vestibular, cuja diferença entre ambos reside apenas no fato de que o primeiro tem um caráter de unicidade nacional no que se refere à realização do exame por parte dos estudantes. Entretanto, quando analisamos os impactos dessa política nacional de acesso ao ensino superior no Brasil de forma associada à Lei de Cotas, como se observa no quadro de ociosidade das cotas adicionais na UESB, percebemos a gama de desafios que são impostos:

\begin{abstract}
Aos gestores e à organização do sistema universitário para a inclusão qualitativa desse novo perfil de estudante que está ingressando nas universidades. A ampliação do acesso sem a necessária correspondência no atendimento às condições para a permanência, formação acadêmica e para a conclusão da graduação dos estudantes oriundos dos segmentos mais desfavoráveis econômica e culturalmente da sociedade, fará com que, a médio e longo prazo, tais estudantes se tornem os "excluídos do interior" (OLIVEIRA; MAGALHÃES, 2018, p. 182-183).
\end{abstract}

\footnotetext{
${ }^{8}$ Os quantitativos registrados no ingresso sempre sofrem alterações quando se avalia a evolução de matrículas, as quais ocorrem até o limite máximo de $1 / 4$ (um quarto) do início das aulas, que é o prazo final estabelecido regimentalmente para convocações de candidatos suplentes e/ ou ajustamento de matrículas.
} 
SISU OU VESTIBULAR? A POLÍTICA DE ACESSO NO CONTEXTO DE UMA UNIVERSIDADE PÚBLICA DO INTERIOR DA BAHIA

Assim, ainda que um aproveitamento de quase 90\% (noventa por cento) das vagas regulares ofertadas seja um dado animador, entendemos que esse aproveitamento deve ser interpretado de forma indissociável às condições necessárias à permanência, à formação e ao êxito acadêmicos, principalmente daqueles estudantes vulneráveis sócio, econômico e culturalmente. Conforme esclarece a pró-reitora de graduação da UESB:

Nós estamos cumprindo a nossa função social nesse processo de democratização dessas vagas públicas; está tendo também uma democratização do uso delas pela comunidade e, diferente do que muito se fala, os maiores beneficiados são os moradores dos territórios de identidade que pertence a UESB (PRÓ-REITORA DE GRADUAÇÃO, 29/11/2017).

Quanto ao perfil regional dos estudantes que ingressam nos cursos de graduação da UESB, tanto pelo SiSU quanto pelo Vestibular, retratados no gráfico 3, constata-se que a maioria é oriunda do próprio Estado da Bahia, com grande predominância de estudantes matriculados moradores nas próprias cidades-sede dos campi da universidade: Vitória da Conquista, Jequié e Itapetinga.

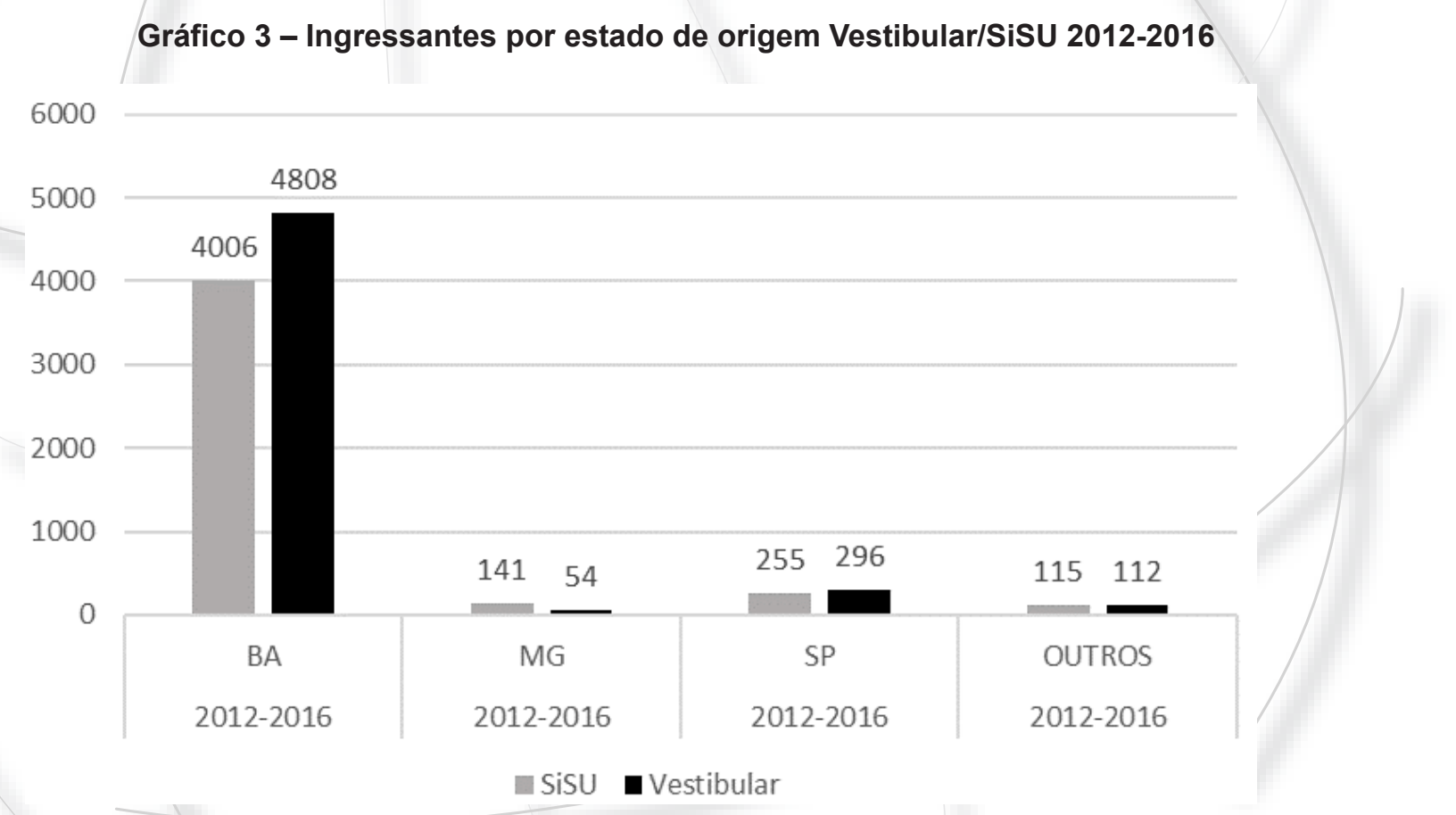

Fonte: Fonte: Dados da pesquisa.

Entretanto, as IES precisam, de forma proativa, se atentar para o fato de que essa realidade tende a mudar com a consolidação temporal do SiSU, tendo em vista que

Além de alunos em condições de vulnerabilidade socioeconômica, a universidade precisa se preparar para receber - e formar - alunos de diversas partes do país (já que o SISU favorece a mobilidade pelo território na concorrência pelas vagas) e com históricos de vida e capital cultural os mais diversos (Oliveira; MagaIhães, 2018, p. 182-183).

Por outro lado, os dados ainda revelam que, embora o SiSU oportunize a mobilidade de candidatos para qualquer região do Brasil, o comportamento de ocupação das vagas por estado federativo de origem, demonstra que a UESB tem recebido um grande número de candidatos do próprio Estado da Bahia, atendendo às populações 
SISU OU VESTIBULAR? A POLÍTICA DE ACESSO NO CONTEXTO DE UMA UNIVERSIDADE PÚBLICA DO INTERIOR DA BAHIA

Daniel Cardoso Alves

locais e cumprindo com a função social de promover o desenvolvimento regional prevista no seu Regimento Geral. Contudo, os 26 (vinte e seis) estados brasileiros e o Distrito Federal estão representados no número de estudantes que ingressam na UESB, sendo que, com exceção do Estado de Minas Gerais que registra um maior quantitativo de estudantes oriundos do SiSU em comparação ao Vestibular, os números de ingressos pelo SiSU e pelo Vestibular de estudantes oriundos do Estado da Bahia são bem equiparados, ou seja, do total de 9.787 (nove mil, setecentos e oitenta e sete) estudantes ingressantes por ambos processos no período de 2012 a 2016, 90\% (noventa por cento) são oriundos do Estado da Bahia, sendo que, 41\% (quarenta e um por cento) equivalem ao SiSU e 49\% (quarenta e nove por cento) referem-se ao Vestibular, o que revela uma predominância de candidatos baianos que acessam aos cursos de graduação pelos dois processos seletivos.

Especificamente com relação às cidades das quais procedem esses estudantes baianos, conforme apreende-se do gráfico $57 \%$ (cinquenta e sete por cento) são naturais das cidades em que os campi da UESB estão instalados, cuja diferença entre os quantitativos de ingressantes pelo SiSU e pelo Vestibular, nessas cidades, é inexpressiva ao considerarmos uma evolução de cinco anos, o número total de matrículas e um processo seletivo de caráter nacional. Na cidade de Vitória da Conquista, ingressaram somente 155 (cento e cinquenta e cinco) estudantes a mais pelo Vestibular; na cidade de Jequié, são apenas 91 (noventa e um) estudantes que ingressaram a mais via Vestibular; e na cidade de Itapetinga, o comportamento é semelhante ao verificado nos dois campi anteriores, ou seja, ingressaram 77 (setenta e sete) estudantes pelo Vestibular a mais que o SiSU.

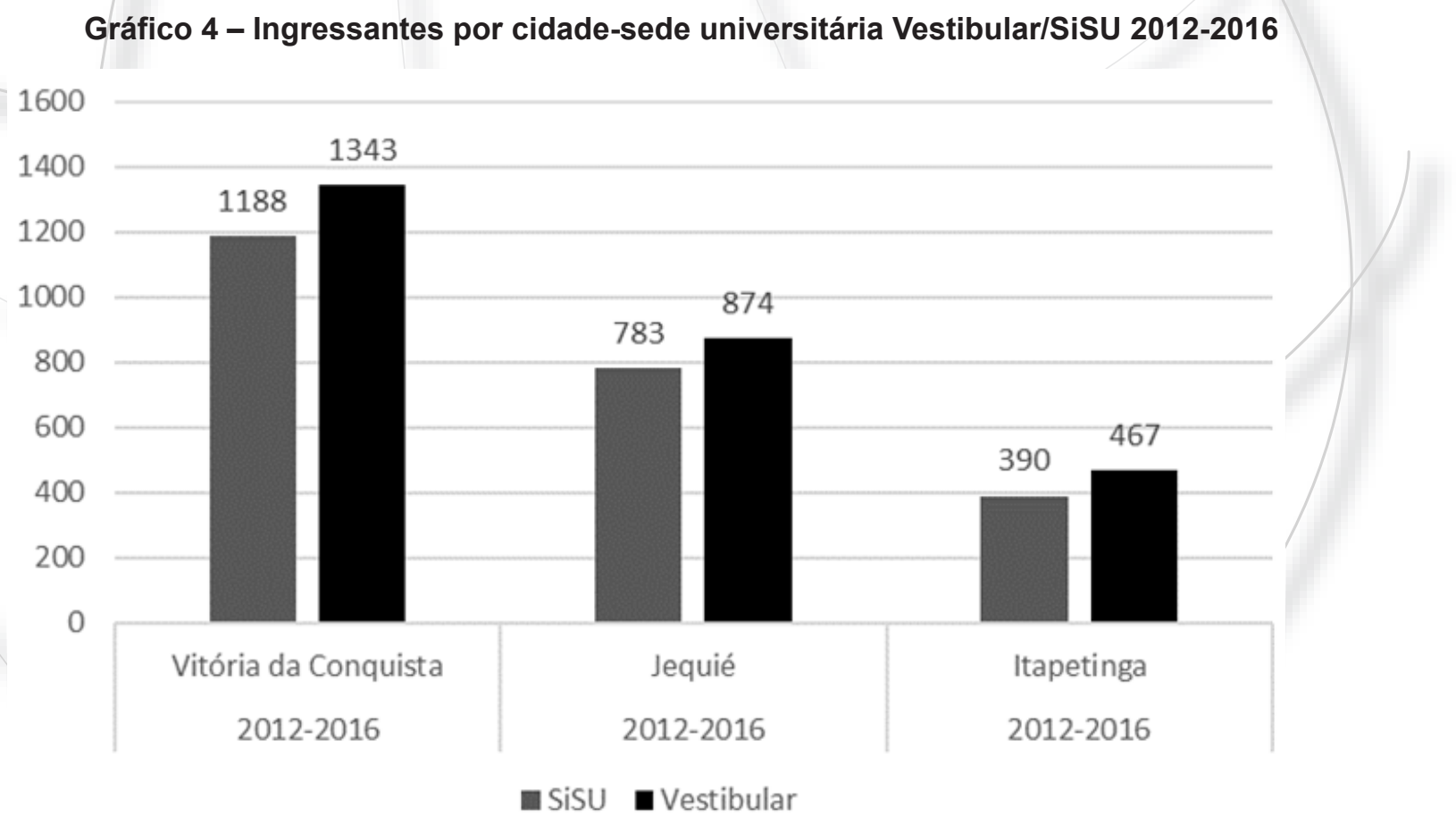

Fonte: Fonte: Dados da pesquisa.

Ainda a respeito dessa distribuição, é curioso o fato de que, dos cursos mais concorridos na UESB, a maioria dos estudantes ingressantes são, também, oriundos do Estado da Bahia e ingressaram por meio do Vestibular. Para citar alguns exemplos, conforme ilustrado no gráfico 5 : 


\section{Gráfico 5 - Ingressantes por estado de origem e curso Vestibular/SiSU 2012-2016}

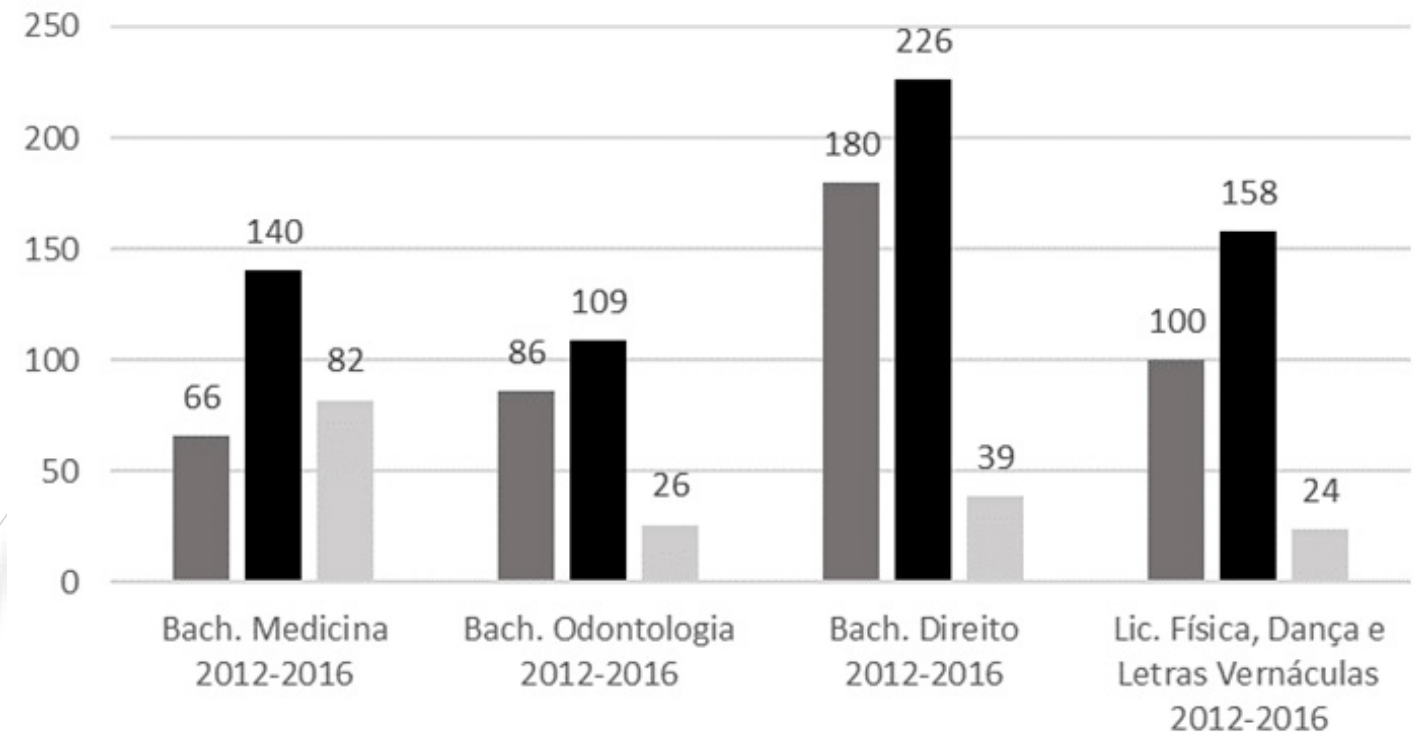

\section{- $\mathrm{SISU}$ BA $\quad$ Vestibular BA $\quad$ Vestibular Outros Estados}

Fonte: Fonte: Dados da pesquisa.

No curso de Bacharelado em Medicina, dos 288 (duzentos e oitenta e oito) ingressantes no período de 2012 a 2016, 71\% (setenta e um por cento) são baianos, em que 22\% (vinte e dois por cento) ingressaram pelo SiSU e $49 \%$ (quarenta e nove por cento) procederam do Vestibular; no curso de Bacharelado em Direito, houve um ingresso, nesse mesmo período, de 445 (quatrocentos e quarenta e cinco) estudantes, dos quais, $40 \%$ (quarenta por cento) acessaram pelo SiSU e 51\% (cinquenta e um por cento) pelo Vestibular, ou seja, 91\% (noventa e um por cento) dos estudantes são oriundos do Estado da Bahia; e no curso de Bacharelado em Odontologia, 221 (duzentos e vinte e um) estudantes ingressaram no período de 2012 a 2016, dos quais, $88 \%$ (oitenta e oito por cento) são baianos, distribuídos em $39 \%$ (trinta e nove por cento) que entraram no curso pelo SiSU e $49 \%$ (quarenta e nove por cento) pelo Vestibular.

Quando se compara os dados dos supracitados cursos, que se configuram como os mais concorridos nos processos realizados pela UESB, com os de cursos de menores concorrências (segundo o relatório de concorrência referente ao ano de 2016 divulgado no site da UESB), verifica-se, nessa mesma Universidade, a exemplo dos Cursos de Licenciatura em Física do Campus de Itapetinga, Licenciatura em Dança do Campus de Jequié e Licenciatura em Letras Vernáculas do Campus de Vitória da Conquista, em conjunto, que ingressaram no período de 2012 a 2016, 282 (duzentos e oitenta e dois) estudantes pelo SiSU e Vestibular nesses cursos, sendo 91\% (noventa e um por cento) baianos, distribuídos em 35\% (trinta e cinco por cento) procedentes do SiSU e 56\% (cinquenta e seis por cento) do Vestibular, o que demonstra um comportamento estatístico semelhante aos cursos de maiores concorrências na UESB.

Esses dados nos instigam a pensarmos que, independente do processo seletivo adotado, seja SiSU ou Vestibular, a questão que não podemos perder de vista é que a ordem que prevalece diante das tentativas de abertura da educação superior a grandes parcelas da população, é a da "[...] manutenção de restrições importantes de posições privilegiadas a grupos socialmente favorecidos [...]" (BOURDIEU, 1998, p. 53), nos instigando os seguintes questionamentos: Quem são esses estudantes matriculados via SiSU ou Vestibular nos tradicionais cursos criados para um seleto grupo privilegiado da sociedade brasileira? Eles têm, de fato, o direito de escolher o curso?

Esses questionamentos se fazem necessários, pois 
A persistência de desigualdades tanto no acesso quanto na conclusão da educação superior estimulou uma série de estudos nacionais sobre o que parece se configurar como uma "democratização segregativa" (DUBET, 2015) desse nível no país. Estudos sociológicos alinhados à literatura sobre estratificação educacional têm mobilizado variadas perspectivas teórico-metodológicas elaboradas para dar conta dos padrões de expansão da educação terciária em todo o mundo. Particularmente, procuram analisar em que medida a massificação do sistema está associada à democratização de oportunidades sociais. Parte importante das evidências recentes têm indicado não apenas o aumento das desigualdades na transição para a educação superior, como o fato de que diferentes grupos sociais acessam diferentemente os distintos segmentos desse nível (BRITO; CARVALHAES; RIBEIRO, 2017 apud HONORATO; ZUCCARELLI, 2018, p. 39).

Como último aspecto abordado na pesquisa, o fato de que, numa universidade pública, $80 \%$ (oitenta por cento) dos estudantes que ingressam nos seus cursos graduação são oriundos de escolas públicas, é revelador de que a combinação SiSU/Vestibular/Ações Afirmativas vem contribuindo qualitativamente para o novo perfil de estudante que está ingressando nas universidades, no caso específico, na UESB, todavia, não podemos perder de vista que

A ênfase na política de expansão e massificação não esgota o projeto de democratização da educação superior. Esse processo só se completará se tivermos igual proporção de crescimento na taxa de concluintes, com integração crescente das camadas marginalizadas socialmente, sobretudo dos estudantes de baixa renda. É necessário visar com igual ênfase o final do processo: a conclusão, com êxito, dos cursos superiores, integrando nesses índices as camadas subalternizadas da população, com garantia de qualidade na formação. A vigilância constante sobre a qualidade dos cursos de graduação, as taxas de conclusão e o perfil socioeconômico dos concluintes e dos que evadem nos parece essencial, não apenas para atestar ou não o sucesso do processo como para produzir feedbacks sobre as políticas adotadas (PAULA; SILVA, 2012, p.7).

Acrescenta-se que, desses $80 \%$ (oitenta por cento) de estudantes procedentes da rede pública de ensíno, $42 \%$ (quarenta e dois por cento) vinculam-se aos vinte e dois cursos (doze bacharelados e dez licenciaturas) existentes no Campus de Vitória da Conquista, 26\% (vinte e seis por cento) estão matriculados nos dezesseis cursos (oito bacharelados e oito licenciaturas) do Campus de Jequié, e 12\% (doze por cento) pertencem aos nove cursos (cinco bacharelados e quatro licenciaturas) do Campus de Itapetinga, conforme constata-se da evolução estatística dos ingressos na UESB no período de 2012 a 2016 ilustrada no gráfico 6: 


\section{Gráfico 6 - Ingressantes por escola de origem Vestibular/SiSU 2012 - 2016}

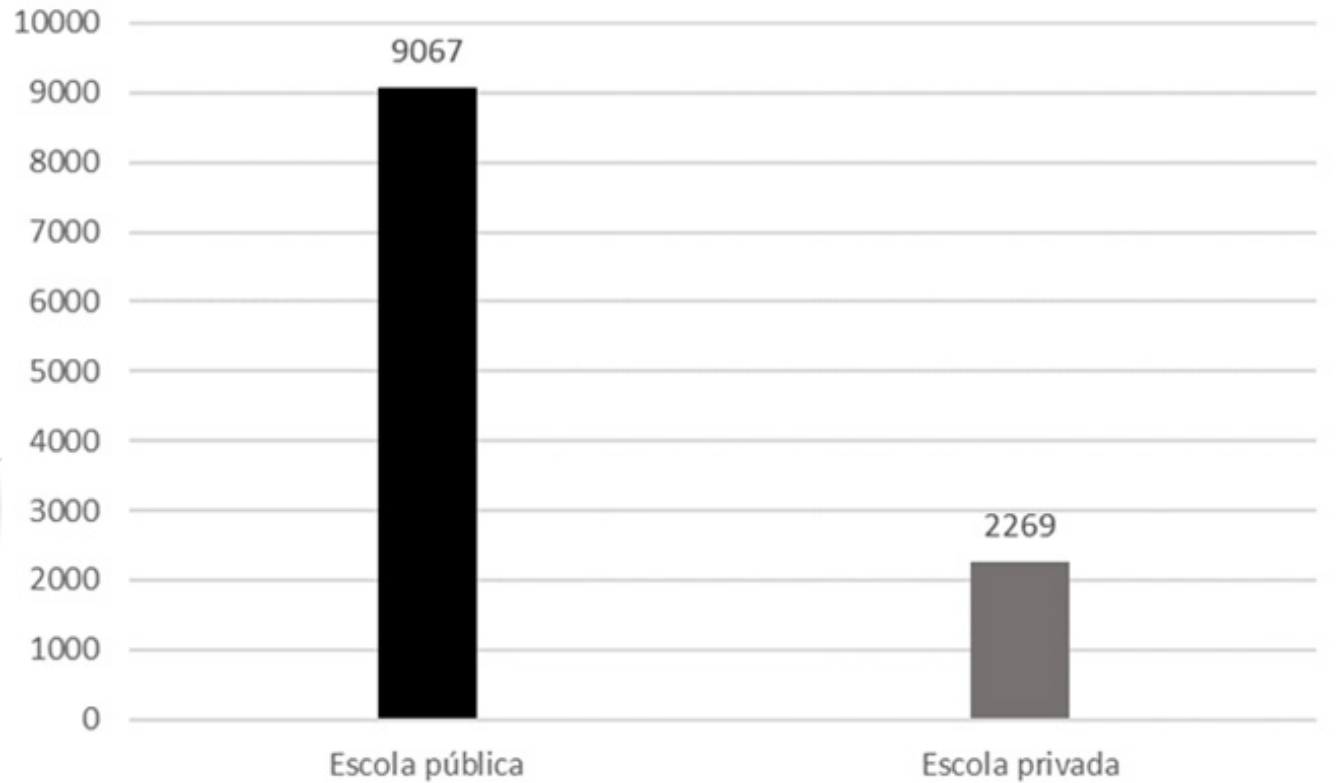

Fonte: Fonte: Dados da pesquisa.

A UESB se constitui, assim, como uma IES com um corpo discente majoritariamente proveniente da rede pública de ensino, inclusive nos tradicionais cursos de elite, o que revela, no mínimo, êxitos da combinação das políticas híbridas de acesso com as Ações Afirmativas implementadas pela instituição. No entanto, não sejamos ingênuos, visto que,

[...] Apesar de alguma abertura, o sistema permanece muito desigual porque tanto a origem social quanto a raça ou o sexo fazem uma diferença enorme na possibilidade de os indivíduos fazerem todo o percurso com sucesso. Isso significa que são os fatores sociais que estão definindo a trajetória dos estudantes, e não a própria instituição. Como eu gosto de dizer, mesmo não agradando a muita gente: o sistema de ensino superior abre, ao lado da porta principal, uma série de entradas de serviço para que grupos específicos de pessoas entrem pela entrada de serviço e saiam por uma mais de serviço ainda. A qualidade das posições que esses grupos ocupam no mercado de trabalho pode ser vista em estudos recentes de desigualdades no mercado (BARBOSA, 2018, p. 27).

Esses dados não podem camuflar a importância que a política de permanência assume num cenário universitário que possui esse perfil de alunado cada vez mais diversificado.

\section{CONSIDERAÇÕES FINAIS}

Dos resultados obtidos, foi possível observar que as políticas públicas educacionais de acesso à educação superior devem ser implantadas numa perspectiva para além do aspecto quantitativo, ou seja, não se restringem ao acúmulo de matrículas, devendo priorizar a qualidade acadêmica e a justiça social, uma vez que, não basta ampliar o acesso à universidade a partir da criação de novos sistemas de seleção sem, contudo, garantir a permanência e a conclusão com sucesso de sujeitos que, historicamente, estiveram à margem da educação superior no país, tendo em vista, conforme Houri (2018), há muitas contradições implícitas no suposto projeto de democratização da educação superior no Brasil, dentre as quais: o caráter privatista com a oferta de cursos de formações humana e profissional aligeiradas e acríticas, a falta de investimentos no sistema público de ensino e o elevado número de 
evasão constatado na educação superior que, segundo o INEP (2016), gira em torno de 40\% (quarenta por cento).

O SiSU, apesar de não ser resultado de uma política interna, foi aderido pela UESB no ano de 2012 e, num recorte temporal de cinco anos em execução como processo seletivo paralelo ao Vestibular institucional, vem possibilitando, de forma quantitativa semelhante ao Vestibular interno, que estudantes oriundos de escolas públicas, com perfil socioeconômico desfavorecido, de grupos étnico-raciais diversos e moradores da região geográfica na qual se insere a universidade, estejam presentes, em maioria, nos 47 (quarenta e sete) cursos de graduação oferecidos pela UESB.

Contudo, um sistema de seleção já é, na sua essência, excludente, uma vez que, tem como mecanismo selecionar para atender à demanda, o que significa dizer que uma parcela excedente ficará à margem e continuará a aspirar pelo acesso ao ensino superior. É contra essa lógica que as universidades devem medir esforços para a promoção de políticas de acesso que não se findam na técnica seletiva, pelo contrário, que por meio de ações contínuas, crescentes e interligadas, assegurem as condições necessárias para que haja um cursus universitário exitoso por parte daqueles beneficiados por qualquer que seja a política de acesso. Em outras palavras, não se pode promover o acesso ampliado, democrático e perene à universidade de forma dissociada do conjunto de medidas, no mínimo, atenuantes dos fatores segregacionistas e isoladamente insuficientes, capaz de transpor os entraves que se apresentam na educação superior.

Ao finalizar esta pesquisa, não nos remetemos a uma conclusão, pois consideramos que, apesar da estratégia 12.16 do PNE apontar para o fim dos vestibulares isolados enquanto processos seletivos, ainda estão a ser analisadas outras variáveis que implicam numa definição acerca da adoção institucional do SiSU como forma exclusiva de seleção dos estudantes, dentre as quais, as relacionadas à evasão, à permanência, à integralização e a um debate que se insere na discussão mais profunda sobre os direitos de minorias e maiorias sociais.

Optar por SiSU ou Vestibular não nos parece uma política acertada, visto que, no contexto da UESB, além de ser precoce essa opção, não minimizaria o fato de que, a qualidade do acesso ao ensino superior não se resume à técnica de seleção em si adotada, mas vincula-se a um conjunto de ações que mesclem exclusões de diversas ordens,

Ressalta-se, por fim, que os achados deste estudo dizem respeito a um contexto universitário específico, valendo-se de um recorte temporal de cinco anos, o que requer a realização de novos estudos para a investigação de contextos espaço-temporais distintos, podendo servir de parâmetro a adoção da metodologia apresentada, desde que aperfeiçoada e adequada à realidade investigada.

\section{REFERÊNCIAS}

AFONSO, Almerindo Janela. Mudanças no Estado-avaliador: comparativismo internacional e teoria da modernização revisitada. Revista Brasileira de Educação, v.18, n.53, 2013.

AFONSO, Almerindo Janela. Avaliação educacional: regulação e emancipação. 4.ed. São Paulo: Cortez, 2009.

BAHIA. Universidade Estadual do Sudoeste da Bahia (UESB). Cursos de Graduação. Disponível em: http://www2. uesb.br/cursos-de-graduacao/. Acesso em: 17 nov. 2017.

BAHIA. Plano de Desenvolvimento Institucional 2013 a 2017. Disponível em: http://www2.uesb.br/pdi/arquivos/PDI-UESB-2013-2017.pdf. Acesso em: 17 nov. 2017.

BAHIA. Regimento Geral. Disponível em: http://www2.uesb.br/transparencia/uploads/arquivos/ANEXO_REGIMENTO_UESB.pdf. Acesso em: 17 nov. 2017.

BAHIA. Resoluções. Disponível em: http://www2.uesb.br/transparencia/resolucoes/consu. Acesso em: 17 nov. 2017. 
BARBOSA, Maria Ligia de Oliveira. Ensino Superior: Massificação ou Democratização? In: Educação superior no Brasil contemporâneo: estudos sobre acesso, democratização e Desigualdades. Heringer, Rosana, 1965. $1^{\text {a }}$. ed.(organização) Rio de Janeiro: Faculdade de Educação da UFRJ, 2018. Cadernos do LEPES.

BARROS, Ricardo Paes de; MENDONÇA, Rosane; SANTOS, Daniel Domingues dos; QUINTAES, Giovani. Determinantes do desempenho educacional no Brasil. Pesquisa e Planejamento Econômico, Rio de Janeiro, v. 31, n. 1, 2001.

BLAU, Peter; DUNCAN, Otis Dudley. The American occupational structure. New York: Wiley, 1967.

BOURDIEU, Pierre. Coisas ditas. São Paulo: Brasiliense, 2004.

BOURDIEU, Pierre. Escritos de Educação. Petrópolis: Vozes, 1998.

BRASIL. Decreto n 5.800, de 8 de junho de 2006. Dispõe sobre o Sistema Universidade Aberta do Brasil - UAB. DOU, Brasília, DF, 9 jun. 2006. Disponível em: http://www.planalto.gov.br/ccivil_03/_ato2004-2006/2006/decreto/ d5800.htm. Acesso em: 18 nov. 2017.

BRASIL. Decreto $n^{\circ} 7.234$, de 19 de julho de 2010. Dispõe sobre o Programa Nacional de Assistência Estudantil PNAES. DOU, Brasília, DF, 20 jul. 2010. Disponível em: http://www.planalto.gov.br/ccivil_03/_Ato2007-2010/2010/ Decreto/D7234.htm. Acesso em: 18 nov. 2017.

BRASIL. Decreto $n^{\circ} 8.498$, de 10 de agosto de 2015. Altera o decreto $n^{\circ} 7.790$, de 15 de agosto de 2012, que dispõe sobre financiamento do Fundo de Financiamento Estudantil - FIES. DOU, Brasília, DF, 11 ago. 2015. Disponível em: http://www.planalto.gov.br/ccivil_03/_ato20152018/2015/decreto/D8498.htm. Acesso em: 18 nov. 2017.

BRASIL. Lei no 11.096, de 13 de janeiro de 2005. Institui o Programa Universidade para Todos - PROUNI, regula a atuação de entidades beneficentes de assistência social no ensino superior; altera a Lei no 10.891, de 9 de julho de 2004, e dá outras providências. DOU, Brasília, DF, 14 jan. 2005. Disponível em: http://www.planalto.gov.br/ccivil_03/_Ato2004-2006/2005/Lei/L11096.htm. Acesso em: 17 nov. 2017.

BRASIL. Lei no 12.711, de 29 de agosto de 2012. Dispõe sobre o ingresso nas universidades federais e nas instituições federais de ensino técnico de nível médio e dá outras providências. DOU, Brasília, DF, 30 ago. 2012. Disponível em: http://portal.inep.gov.br/documents/186968/523064/DESIGUALDADE+DE+ACESSO+\%C3\%80+EDUCA\% C3\%87\%C3\%83O+SUPERIOR+NO+BRASIL+E+O+PLANO+NACIONAL+DE+EDUCA $\%$ C3\%87\%C3\%83O/0977f 6b9-281d-48df-aeb2-2e5942dc26d6?version=1.2. Acesso em: 18 nov. 2017.

BRASIL. Lei no 13.005, de 25 de junho de 2014. Aprova o Plano Nacional de Educação - PNE e dá outras providências. DOU, Brasília, DF, 16 jun. 2014. Disponível em: http://www.planalto.gov.br/ccivil_03/_Ato2011-2014/2014/Lei/ L13005.htm. Acesso em: 18 nov. 2017.

BRASIL. Ministério da Educação (MEC). Censo da educação superior: Notas Estatísticas 2017. Disponível em: http://download.inep.gov.br/educacao_superior/censo_superior/documentos/2018/censo_da_educacao_ superior_2017notas_estatisticas2.pdf/.Acesso em: 20 nov. 2017.

BRASIL. FIES: Programa de Financiamento Estudantil. Disponível em: http://sisfiesportal.mec.gov.br/. Acesso em: 
SISU OU VESTIBULAR? A POLÍTICA DE ACESSO NO CONTEXTO DE UMA UNIVERSIDADE PÚBLICA DO INTERIOR DA BAHIA

20 nov. 2017.

BRASIL. Portaria Normativa n 438, de 13 de fevereiro de 2009. Dispõe sobre procedimentos para adesão de instituições, inscrição, seleção e contratação de candidatos ao processo seletivo do Fundo de Financiamento ao Estudante do Ensino Superior - FIES referente ao primeiro semestre de 2009. DOU, Brasília, DF, 16 fev. 2009. Disponível em: http://semesp.org.br/portal/pdfs/juridico2009/Portarias/16.02.09/por_2.pdf. Acesso em: 20 nov. 2017.

BRASIL. Portaria Normativa $n^{\circ}$ 807, de 28 de junho de 2010. Revoga a Portaria MEC 438, de 28 de maio de 1998 e institui o Exame Nacional do Ensino Médio - Enem. DOU, Brasília, DF, 21 jun. 2010. Disponível em: http://www. normasbrasil.com.br/norma/portaria-807-2010_226878.html. Acesso em: 20 nov. 2017.

BRASIL. PROUNI: Programa Universidade Para Todos. Disponível em: http://prouniportal.mec.gov.br/. Acesso em: 20 nov. 2017.

BRASIL. Resumo técnico: Censo da Educação Superior 2014. Disponível em: http://portal.inep.gov.br/documents/186968/484154/Resumo+T\%C3\%A9cnico+-+Censo+da+Educa\%C3\%A7\%C3\%A3o+Superior+2014/18f3 1c19-9885-4d1d-ba53-06008b11531e?version=1.0. Acesso em: 20 nov. 2017.

BRASIL. SiSU: Sistema de Seleção Unificada. Disponível em: http://www.sisu.mec.gov.br/legislacao. Acesso em: 20 nov. 2017.

BRITO, Murillo Marschner Alves de. A dependência na origem: desigualdades no sistema educacional brasileiro e a estruturação social das oportunidades. 2014. 270 f. Tese (Doutorado em Sociologia) - Faculdade de Filosofia, Letras e Ciências Humanas, Universidade de São Paulo, São Paulo, 2014.

COLEMAN, James. Equality of educational opportunity. Washington, DC: US Department of Health, Education and Welfare, 1966.

GIL, Antônio Carlos. Métodos e técnicas de pesquisa social. - 6. ed. - São Paulo: Atlas, 2008.

HONORATO, Gabriela; VIEIRA, André; ZUCCARELLI, Carolina. Expansão, diversificação e composição social da área de Educação no ensino superior brasileiro (1995-2015). In: Educação superior no Brasil contemporâneo: estudos sobre acesso, democratização e Desigualdades. Heringer, Rosana, 1965. $1^{\text {a }}$. ed.(organização) Rio de Janeiro: Faculdade de Educação da UFRJ, 2018. Cadernos do LEPES.

HOURI, Mônica de Souza. Evasão e permanência na educação superior - uma perspectiva discursiva - contribuições para o debate. In: Educação superior no Brasil contemporâneo: estudos sobre acesso, democratização e Desigualdades. HERINGER, Rosana (organização). Rio de Janeiro: Faculdade de Educação da UFRJ, 2018. Cadernos do LEPES.

KLITZKE, Melina Kerber. Acesso ao ensino superior: análise do perfil dos ingressantes em cursos de prestígio da UFRJ. In: Educação superior no Brasil contemporâneo: estudos sobre acesso, democratização e Desigualdades. Heringer, Rosana (organização). Rio de Janeiro: Faculdade de Educação da UFRJ, 2018. Cadernos do LEPES.

KLITZKE, Melina Kerber; SANTOS, Tiago Ribeiro; VALLE, Ione Ribeiro. Notas de síntese: uma cartografia do Exame Nacional do Ensino Médio a partir de dissertações e teses. In: FÓRUM INTERNACIONAL DE PEDAGOGIA, 2013, Vitória da Conquista. Anais. Revista FIPED; Ed. Realize, 2013. Disponível em: http://editorarealize.com.br/revistas/ 
SISU OU VESTIBULAR? A POLÍTICA DE ACESSO NO CONTEXTO DE UMA UNIVERSIDADE PÚBLICA DO INTERIOR DA BAHIA

fiped/trabalhos/Trabalho_Comunicacao_oral_

idinscrito_900_c2623e5a7959889fbb8d54be9b85ce23.pdf. Acesso em:16 jul. 2017.

MONT'ALVÃO, Arnaldo. Estratificação educacional no Brasil do século XXI. Dados: Revista de Ciências Sociais, Rio de Janeiro, v. 54, n. 2, 2011.

OLIVEIRA, Antônio José Barbosa de; MAGALHÃES, Rosélia Pinheiro. Acompanhamento acadêmico de estudantes ingressantes pela política de ação afirmativa nos cursos do CCJE/UFRJ: um estudo preliminar. In: Educação superior no Brasil contemporâneo: estudos sobre acesso, democratização e Desigualdades. Heringer, Rosana, 1965. $1^{a}$. ed.(organização) Rio de Janeiro: Faculdade de Educação da UFRJ, 2018. Cadernos do LEPES.

PAULA, Maria de Fátima Costa; SILVA, Maria das Graça Martins. Introdução. In: As políticas de democratização da educação superior nos estados do Rio de Janeiro e de Mato Grosso: produção de pesquisas e questões para o debate. Cuiabá: EdUFMT, 2012.

SAMPAIO, Helena. Ensino Superior no Brasil: desafios locais e globais. In: Educação superior no Brasil contemporâneo: estudos sobre acesso, democratização e Desigualdades. Heringer, Rosana, 1965. 1ª . ed.(organização) Rio de Janeiro: Faculdade de Educação da UFRJ, 2018. Cadernos do LEPES.

SILVA, Nelson do Valle; HASENBALG, Carlos. Recursos familiares e transições educacionais. Cadernos de Saúde Pública, Rio de Janeiro, v. 18, 2002. Suplemento.

SOARES, José Francisco; COLLARES, Ana Cristina. Recursos familiares e o desempenho cognitivo dos alunos do ensino básico brasileiro. Dados: Revista de Ciências Sociais, Rio de Janeiro, v. 49, n. 3, 2006. 